DOI 10.18551/rjoas.2019-06.19

\title{
THE HAPPINESS ANALYSIS OF PEOPLE LIVING WITH HIV AIDS (PLWHA) IN DENPASAR CITY
}

\author{
Pardita Dewa Putu Yudi ${ }^{\star}$, Bendesa I K.G., Sudibia I Ketut, Saskara Ida Ayu Nyoman \\ Faculty of Economics and Business, University of Udayana, Bali, Indonesia \\ *E-mail: yudipardita@gmail.com
}

\begin{abstract}
HIV AIDS is a disease caused by a virus that has not been cured until now. HIV AIDS was expected to reduce the life expectancy of PLWHA so that the expected contribution of PLWHA in the economic sector and social development becomes smaller. Another result of HIV AIDS in the environment is the imposition of social penalties for PLWHA, such as acts of avoidance, exile, rejection, and discrimination. In addition, PLWHA can't do their jobs optimally or even have to lose their jobs because of poor physical condition, so they can lose income. Social, economic, psychological and environmental problems for PLWHA are feared to reduce the quality of life for PLWHA which will have an impact on the happiness of PLWHA themselves. This study aims to find the condition of PLWHA happiness, the difference between happiness of PLWHA with male and female, the influence of socioeconomic factors, psychological factors, and environmental factors on religiosity, as well as the influence of socio-economic factors, psychological factors, environmental factors, and religiosity on PLWHA happiness in Denpasar City. The data used in this study were primary data obtained by observation, structured interviews, and in-depth interviews. The sample used was 148 PLWHA respondents in Denpasar City using the Consecutive Sampling methods. The data obtained then analyzed using the Structural Equation Modeling (SEM) method through the Partial Least Square (PLS) application program. The results of this study are PLWHA in Denpasar City who are predominantly still feeling happy can be interpreted that HIV AIDS does not necessarily eliminate the hope of PLWHA to live happily, while gender does not have a relationship with the happiness level of PLWHA in Denpasar City. Socio-economic factors and environmental factors have a positive and significant effect on the religiosity of PLWHA in Denpasar City, while psychological factors don't affect the religiosity of PLWHA in Denpasar City. Socio-economic factors, psychological factors, and environmental factors do not affect the happiness of PLWHA in Denpasar City directly, but religiosity has a positive and significant effect on the happiness of PLWHA in Denpasar City. It can be said that religiosity mediates in full the relationship between socio-economic factors and environmental factors with the happiness of PLWHA in Denpasar City, while on the other hand religiosity does not mediate the relationship between psychological factors and the happiness of PLWHA in Denpasar City. The happiness of PLWHA in Denpasar City is influenced by its religiosity. PLWHA, who have faith in God, have knowledge about the religion they embrace, and practice the teachings of religion well and can truly feel happiness in their lives. Government policy through socialization and lectures by presenting religious leaders is expected to provide motivation and instil religious values to PLWHA.
\end{abstract}

\section{KEY WORDS}

PLWHA, social economy, psychological, environment, religiosity, happiness.

Development is a continuous process of change to lead to better conditions based on certain norms. The important meaning of development is progress or improvement, growth, and diversification. Research doing by Jaafar, et.al. (2008) prove that the level of income is not the most important in development, but rather the distribution of income evenly, so that can meet the basic needs of everyone, open access to employment, public services, and better quality infrastructure. Happiness is an indicator of the community's response to how development has been carried out so far and then its impacts on human life, therefore, a low 
level of happiness is actually a warning for policymakers to improve development policies to be more oriented on equity and security of quality of life immediately.

One of the development policies implemented by the government to increase community happiness is health development policies. Health is a fundamental development goal. It is the core of fundamental well-being to shape broader human abilities (Todaro and Smith, 2006). Health policies held are related to the health system. According to the WHO definition, the health system is all activities whose main purpose is to improve, maintain and cope with public health complaints. Policies in tackling health complaints of residents in the Province of Bali relate to the improvement of the health system which includes the components of the public health department, hospitals and clinics, as well as doctors and paramedic practice rooms.

Policies are carried to reduce the health complaints of the population and to achieve one of the health development goals, such increase awareness, willingness, and the ability to live healthy for everyone to realize the optimal degree of public health. But it is not easy to achieve this goal, because along the times the various kinds of diseases have emerged that can hinder health development (Mubarak, 2008). The advancement of technology in the health sector is not necessarily able to solve this problem, because there are still some incurable diseases because the medicine has not been found, like HIV AIDS.

AIDS or Acquired Immune Deficiency Syndrome is symptoms and infections or syndromes caused by human immune system damaged by HIV (Human Immunodeficiency Virus). HIV is a virus that can weaken immunity in humans. The Real data of the number of people living with HIV AIDS (PLWHA) that are not recorded in various health service facilities that the real number far more than the official data recorded. The number of findings of HIV AIDS cases in Bali Province until 2017 is quite high; it will certainly tarnish the good name of Bali as the Island of the Gods, which is one of the excellent tourist destinations in Indonesia. The following Figure 1 describes the graph of the cumulative number of HIV AIDS cases based on districts in the Province of Bali in 1987-2017.

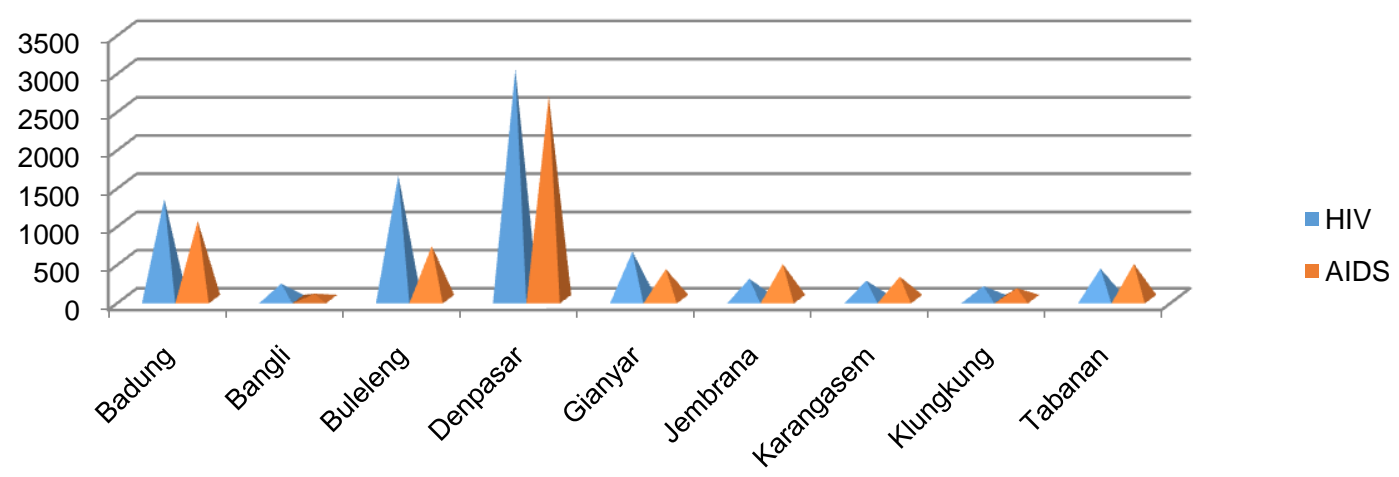

Figure 1 - Number of Cumulative HIV AIDS Cases by Regency / City in Bali Province 1987-2017 (Source: Bali Provincial AIDS Commission, 2018)

Figure 1 shows that the cumulative HIV AIDS cases in Denpasar City in 1987-2017 were the highest compared to other districts in Bali Province. The high number of HIV AIDS cases in Denpasar City has the potential to increase the percentage of PLWHA who do not get health services or cannot be reached by health workers. This can occur because of constraints of factors such as PLWHA who do not dare to carry out HIV AIDS and PLWHA are introvert, causing more PLWHA to be displaced then not being registered with health services in Denpasar City. This situation is feared to have an impact on the condition of happiness of PLWHA because it can affect the decrease in positive emotions that are felt such as feelings of joy, optimism, love, and pride.The high number of people living with HIV can be expected to reduce life expectancy later because more people are expected to live in a shorter period of time, the contribution expected from PLWHA to the national economy and 
social development becomes smaller and less reliable. The consequences of HIV AIDS in the environment also include impacts on households. PLWHA cannot do their jobs optimally, or even have to lose their jobs because their physical condition is not good, so they have the potential to lose income. One of the most visible impacts is the imposition of social penalties for PLWHA including human rights violations. The following is a picture of 2 types of human rights violations against PLWHA in Denpasar City.

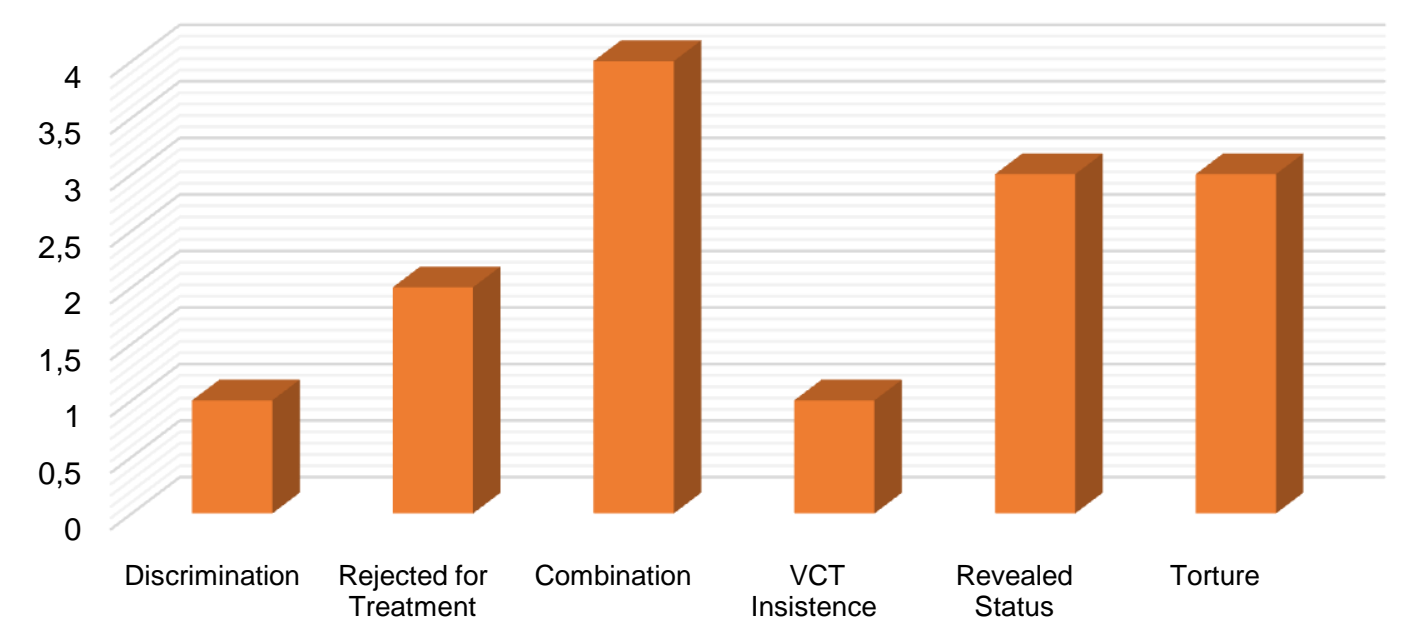

Figure 2 - Types of Human Rights Violations against PLWHA in Denpasar City in 2017 (Source: Legal Aid Institute of Bali Province, 2018)

The social and economic impacts caused by the high spread of HIV AIDS are not only a problem for the government but also PLWHA in general, moreover, PLWHA will feel the psychological problems caused by HIV AIDS. Social, economic, and psychological problems for PLWHA are feared to reduce the quality of life for PLWHA which will have an impact on the happiness of PLWHA. Seligman (2005) explains that happiness is a concept that refers to positive emotions felt by individuals. The definition of happiness is a subjective concept because each individual has different benchmarks. Each individual also has different factors so that can bring happiness to them. These factors include social economic factors, psychological factors, environmental factors, and religiosity

\section{METHODS OF RESEARCH}

This research was conducted in Denpasar City because the cumulative number of PLHIV recorded in health services in Denpasar City was the highest compared to other districts in Bali Province, besides this research was conducted because there was not enough information about the happiness of PLWHA. This study uses qualitative data and quantitative data, both types of data are obtained through field research so that both include primary data. Research on the analysis of happiness of people living with HIV AIDS (PLWHA) in Denpasar resulted in these two types of data, to obtain it used methods of data collection through observation, structured interviews (interviews), and in-depth interviews (indepth interviews).

Data from Bali Provincial Health Office states that the population of people with HIV AIDS (PLWHA) recorded in Denpasar City health services in 2017 reached 880 people. This amount is quite large and it is not possible to learn everything in the population because of limited funds, energy, and time so that the sample studied in the population can be used (Husein, 2003). The sample is part of the number and characteristics possessed by the population (Sugiyono, 2007). The number of samples that must be sought in this study are 148 people with HIV AIDS (PLWHA) in the city of Denpasar using the method of determining the sample, Consecutive Sampling. Consecutive Sampling is a method of selecting samples 
by specifying subjects that meet the research criteria included in the study until a certain period of time so that the number of respondents can be fulfilled.

Structural Equation Modeling (SEM) is used to produce a model that feasible. This analysis is a multivariate analysis technique that can analyze complex variable relationships. With this technique, it is expected that the relationship between variables can be thoroughly explained. The calculation process is assisted by the Partial Least Square (PLS) application program, which is Smart PLS software version 3.2.8. According to Wold in Ghozali (2008), Partial Least Square is a powerful analytical method because it is not based on many assumptions. Data does not have to be multivariate normally distributed (indicators with category, ordinal scale, intervals until ratios can be used on the same model), samples do not have to be large and can be used simultaneously for reflective and formative models.

\section{RESULTS OF STUDY}

Respondents in this study were people with HIV AIDS in Denpasar City. The data obtained are then divided based on the characteristics of the research respondents. The following is Figure 3 which shows the characteristics of respondents by gender.

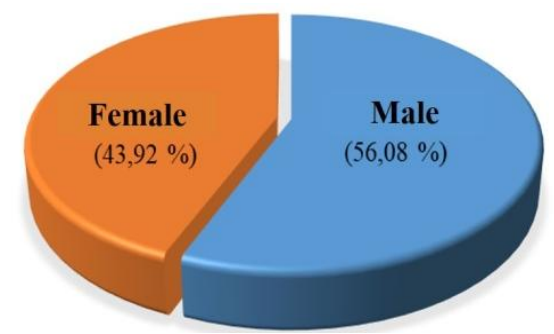

Figure 3 - Respondent Characteristics by Gender (Source: Data Processed, 2019)

Based on Figure 3 the characteristics of respondents by gender were dominated by men with 83 PLWHA who had a percentage of happiness level 8.44 percent less happy, 62.65 percent happy, and 28.91 percent were very happy, while women numbers are 65 PLWHA with a percentage happiness level 6.16 percent is unhappy, 60 percent are happy, and 33.84 percent are very happy. Statistical tests state that gender does not have a relationship with the happiness level of PLWHA with a significance value of 0.819 and the value of Chi Square counts 0.400 less than the Chi-Square table value of 5.991.

The happiness level of PLWHA in Denpasar City varies, based on Figure 4 shows that dominant PLWHA still feel happy even though they have HIV AIDS. This condition can mean that HIV AIDS does not necessarily reduce the happiness level of PLWHA in general because there are other factors that can affect the happiness of PLWHA, including socioeconomic, psychological, environmental, and religiosity factors. The following is a picture of 4 characteristics of respondents based on their level of happiness.

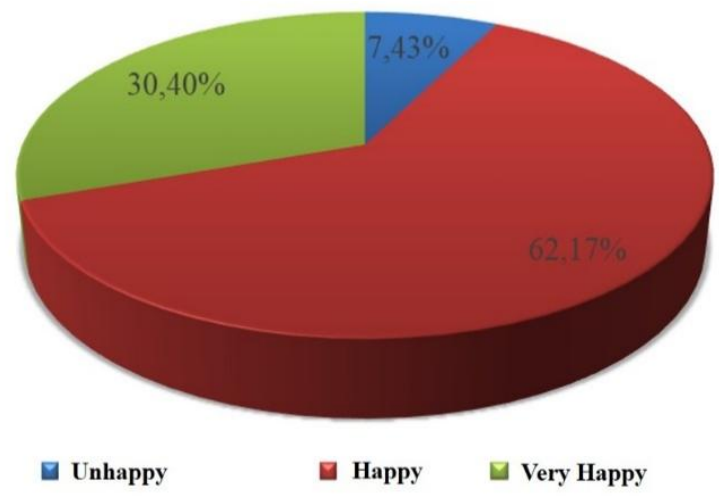

Figure 4 - Respondent Characteristics by Level of Happiness (Source: Data Processed, 2019) 
The process of data analysis uses the Partial Least Square (PLS) application program, which is Smart PLS software version 3.2.8. Figure 5 shows the $R$-square value of variable $Y_{1}$ of 0.211 which means that 21.1 percent of the variation in the variable religiosity on PLWHA is influenced by socio-economic factors, psychological factors, and environmental factors while the remaining 78.9 percent are influenced by other factors outside the model. The variable $Y_{2} R$-square value is 0.194 which means that 19.4 percent of the variation in happiness variables on PLWHA is influenced by socio-economic factors, psychological factors, environmental factors, and religiosity while the remaining 80.6 percent are influenced by other factors outside the model. The following is a picture of the results of an analysis of the happiness of people with HIV AIDS (PLWHA) in Denpasar City.

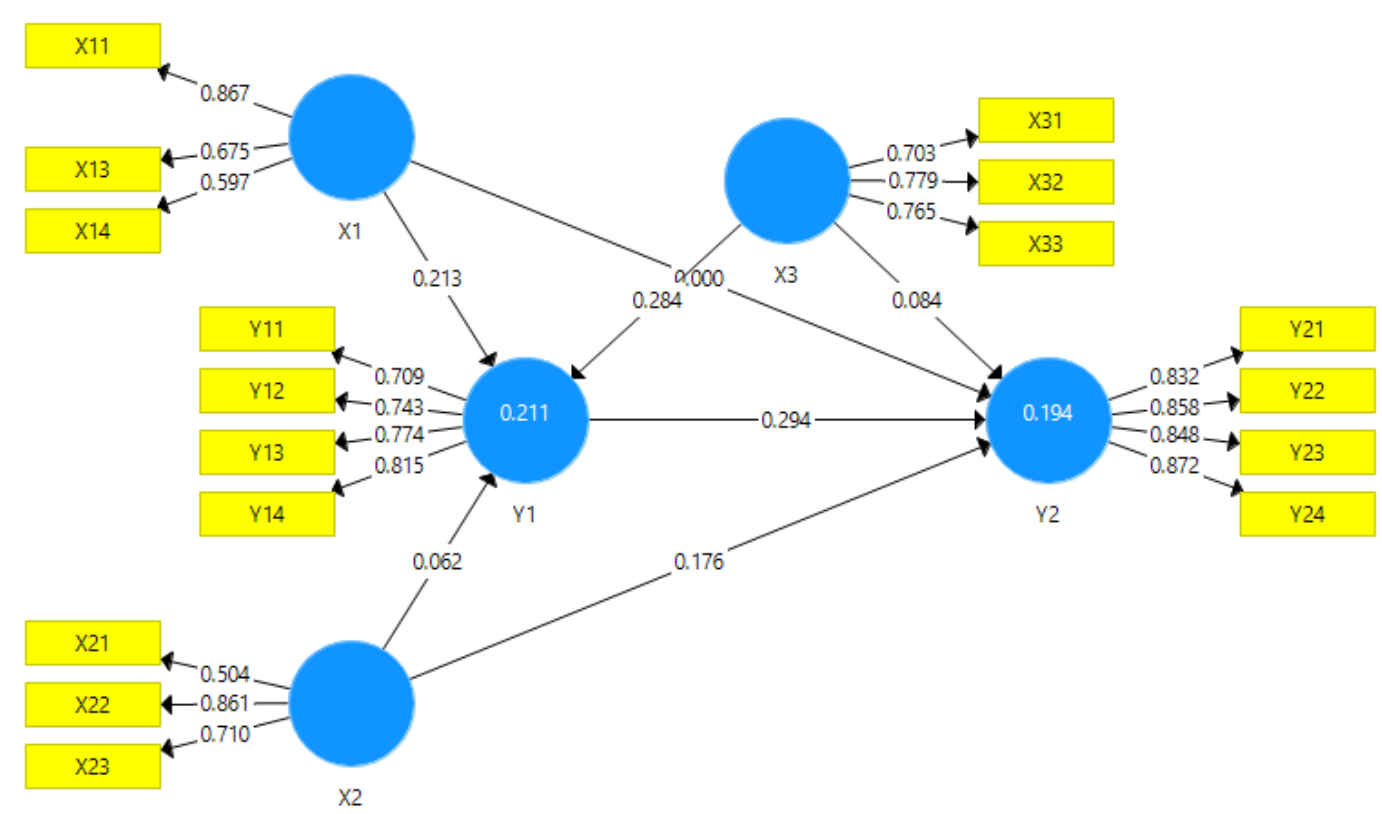

Figure 5 - Research Results Analysis of Happiness for People Living with HIV AIDS (PLWHA) in Denpasar City (Source: Research Results, 2019)

The total indirect effect of socio-economic factors $\left(X_{1}\right)$ on happiness $\left(Y_{2}\right)$ PLWHA through religiosity $\left(Y_{1}\right)$ is 0.0627 while the direct influence of socio-economic factors $\left(X_{1}\right)$ on happiness $\left(\mathrm{Y}_{2}\right)$ PLWHA is 0.0004 . This means that the indirect effect of socio-economic factors $\left(X_{1}\right)$ on happiness $\left(Y_{2}\right)$ PLWHA through religiosity $\left(Y_{1}\right)$ is greater than the direct influence between socio-economic factors $\left(X_{1}\right)$ and happiness $\left(Y_{2}\right)$ PLWHA. The total indirect effect of psychological factors $\left(X_{2}\right)$ on happiness $\left(Y_{2}\right)$ PLWHA through religiosity $\left(Y_{1}\right)$ is 0.0182 while the direct effect of psychological factors $\left(X_{2}\right)$ on happiness $\left(Y_{2}\right)$ for PLWHA is 0.1765 . This shows directly the influence of psychological factors $\left(X_{2}\right)$ on happiness $\left(Y_{2}\right)$ PLWHA is greater than the indirect influence of psychological factors $\left(X_{2}\right)$ on happiness $\left(Y_{2}\right)$ PLWHA through religiosity $\left(\mathrm{Y}_{1}\right)$.

The total indirect effect of environmental factors $\left(X_{3}\right)$ on happiness $\left(Y_{2}\right)$ PLWHA through religiosity $\left(Y_{1}\right)$ is 0.0837 while the direct effect of environmental factors $\left(X_{3}\right)$ on happiness $\left(Y_{2}\right)$ for PLWHA is 0.0840. It shows the influence of environmental factors $\left(X_{3}\right)$ on happiness $\left(Y_{2}\right)$ PLWHA is greater than the indirect influence of environmental factors $\left(X_{3}\right)$ on happiness $\left(Y_{2}\right)$ PLWHA through religiosity $\left(Y_{1}\right)$. Meanwhile, the significance value of the relationship between variables can be seen from the numbers of $p$ values, Table 1 the significance value of the happiness analysis of people living with HIV AIDS (PLWHA) in Denpasar City.

Based on Table 1 it can be explained that socio-economic factors $\left(\mathrm{X}_{1}\right)$, psychological factors $\left(X_{2}\right)$, and environmental factors $\left(X_{3}\right)$ directly did not significantly influence happiness $\left(Y_{2}\right)$ with $p$ values more than 0.05 . While directly religiosity $\left(Y_{1}\right)$ has a significant effect on 
happiness $\left(Y_{2}\right)$ with $p$ values 0.009 less than 0.05 . Indirectly socio-economic factors $\left(X_{1}\right)$ and environmental factors $\left(X_{3}\right)$ have a significant effect on happiness $\left(Y_{2}\right)$ through religiosity $\left(Y_{1}\right)$, so that it can be interpreted that religiosity $\left(Y_{1}\right)$ mediates in full the relationship between socioeconomic factors $\left(X_{1}\right)$ and environmental factors $\left(X_{3}\right)$ with happiness $\left(Y_{2}\right)$. Meanwhile, indirectly psychological factors $\left(X_{2}\right)$ have no significant effect on happiness $\left(Y_{2}\right)$ through religiosity $\left(Y_{1}\right)$ so that religiosity $\left(Y_{1}\right)$ does not mediate the relationship between psychological factors $\left(\mathrm{X}_{2}\right)$ and happiness $\left(\mathrm{Y}_{2}\right)$.

Table 1 - The Significance Value of Happiness Analysis of People Living with HIV AIDS (PLWHA) in Denpasar City

\begin{tabular}{ccc}
\hline Variables & $P$ Values & Information \\
\hline $\mathrm{X} 1 \rightarrow \mathrm{Y} 1$ & 0,041 & Significant \\
$\mathrm{XI} \rightarrow \mathrm{Y} 2$ & 0,997 & Not Significant \\
$\mathrm{X} 2 \rightarrow \mathrm{Y} 1$ & 0,502 & Not Significant \\
$\mathrm{X} 2 \rightarrow \mathrm{Y} 2$ & 0,134 & Not Significant \\
$\mathrm{X} 3 \rightarrow \mathrm{Y} 1$ & 0,001 & Significant \\
$\mathrm{X} 3 \rightarrow \mathrm{Y} 2$ & 0,394 & Not Significant \\
$\mathrm{Y} 1 \rightarrow \mathrm{Y} 2$ & 0,009 & Significant \\
\hline
\end{tabular}

Source: Data Processed, 2019.

\section{DISCUSSION OF RESULTS}

A person's happiness generally does not depend on one particular thing, as well as for people with HIV AIDS (PLWHA). There are many factors that can bring about happiness even though PLWHA are constrained by health problems. Based on this study, of 148 PLWHA respondents in Denpasar City there was a variation in the level of happiness felt, with the details of 62.17 percent of PLHIV feeling happy, 30.40 percent very happy, and 7.43 percent less happy. Research Arriza, et al. (2011) states that the factors that influence PLHIV in reconstructing happiness include internal, external, and religiosity factors. Regarding religiosity, PLWHA who have knowledge of religion (intellectual), apply religious teachings are more grateful and obey prayer or worship tend to be happier than others.

The happiness of PLWHA in Denpasar City is directly influenced by religiosity, it shows that a religious approach is needed to build the spirit and self-confidence of PLWHA in their environment. Meanwhile, this study found that out of 83 PLWHA who had male percentage of happiness level 8.44 percent were unhappy, 62.65 percent were happy, and 28.91 percent were very happy, while women were 65 PLWHA with a percentage level of happiness 6.16 percent are unhappy, 60 percent are happy, and 33.84 percent are very happy. The data can mean the happiness level of PLWHA by gender does not have a significant difference. According to Eddington and Shuman (2005), women have a higher level of negative affect and higher levels of depression compared to men. This might happen because women show this feeling more often than men who often hide their feelings.

Socio-economic factors have a positive and significant effect on the religiosity of PLWHA in Denpasar City, this is consistent with Thouless's (2000) statement that education or teaching and various social pressures (social factors) include all social influences in the development of religious attitudes, including education from parents social traditions, pressure from the social environment to adjust with various opinions and attitudes agreed upon by the environment have an effect on one's religiosity. Quality PLWHA social life, both in maintaining relationships in the community and family environment or receiving without discrimination causes a sense of gratitude for PLWHA in their lives which is expressed in a way that they always get closer to God. Meanwhile, sufficient economic conditions have a positive impact on the religiosity of PLWHA. According to Popova (2019), good finances can stimulate activities to carry out activities related to the field of religion.

Psychological factors have no effect on the religiosity of PLWHA in Denpasar because the fact that HIV AIDS cannot be cured causes it is always on the minds of PLWHA so that however the psychological state of PLWHA will not affect their religiosity. The results of this study are inversely proportional to the statement of Daradjat (2003), that a person's religiosity 
can be formed because the desire to live better and not give up with a disappointing situation and there is inner conflict or inner conflict and feeling tension, like a condition where a person feels unable to deal with various problems in life. Physical and psychological shocks that are faced cause PLWHA need a lot of time for the process of healing and self-acceptance of their lives.

Environmental factors have a positive and significant effect on the religiosity of PLWHA in Denpasar City. The family environment is the smallest system of social life and is the place where someone first learns about various things, like about religiosity. Status as a PLWHA does not prevent the respondent from becoming a more religious person, this happens because religiosity can be formed from self-will which encourages a person to submit to God (Rachmat, 2004). Social and environmental support such as solicitation and suggestions, such as moral and material assistance made by leaders and religious leaders to someone who experiences anxiety and misery in life can also make the religiosity of PLWHA increase (Daradjat, 2003).

Socio-economic factors do not affect the happiness of PLWHA in Denpasar City. The results of this study are inversely proportional to Carr's (2004) statement, that individuals who have a higher level of happiness generally have a satisfying social life and spend a lot of time socializing. Support from family or people around can have a positive impact on the happiness of PLWHA. Living in a city causes PLWHA to have limited association with the people around them so that it closes the possibility for them to get support or motivation. Moreover, most PLWHA has not opened their status in public because of fears of discrimination, humiliation and rejection from their environment. Status as a PLWHA does not prevent them from working daily to fulfil their daily needs, even though it requires a lot of money in the treatment process, PLWHA can allocate their income for other needs because most of them already have health insurance.

Psychological factors do not affect the happiness of PLWHA in Denpasar City. The condition of PLWHA in accepting the reality of living with HIV AIDS causes their physical and mental conditions to decline. It can also depend on PLWHA in perceiving their health condition after being positive for HIV AIDS. Seligman (2005) states that health that can affect happiness is health that perceived by individuals (subjective health), not actual health (objective health). Fulfilment of access to medicines, adequate health services, and health insurance has not guaranteed the happiness of PLWHA. Drugs that are PLWHA consumption can reduce the development of HIV AIDS, but not a few of them have to withstand the pain of the side effects of the drug. Most PLWHA needs more rest time to maintain their body condition so that they will take a lot of time to recover their health.

Environmental factors directly do not affect the happiness of PLWHA in Denpasar City. PLWHA need adaptation to the disease, the process needs to be supported by a conducive environment. According to Szaflarski (2017), one way to reduce stigma in the environment is to educate the public and involve religious leaders in the development of interventions. The negative stigma elimination intervention is recommended to be the main focus in helping healing PLWHA. Infected with HIV AIDS causes most PLWHA to struggle harder in living their lives. Worsening health conditions can reduce the confidence of PLWHA, so not a few of them sometimes care less about other things in their lives. Good environmental conditions, such as the condition of a decent home, the absence of a threat of natural disasters, and adequate security are not the main priorities in the process of healing and the formation of enthusiasm in PLWHA.

Socio-economic, psychological, and environmental factors are very important for PLWHA, but there is a perception in the minds of PLWHA that HIV AIDS cannot be cured causing no significant influence on the happiness of PLWHA in Denpasar City, therefore not only human relations are needed but also the relationship between PLWHA and God seen from its religiosity. Religiosity has a positive and significant effect on the happiness of PLWHA in Denpasar City, according to Eddington and Shuman's statement (2005) that there is a significant correlation between happiness and one's belief in religion, the strength of one's relationship with God, worship, and participation in religious activities. Religious experience or beliefs that someone has makes a person have a meaningful feeling in his life. 
Religion or religion is also able to fulfil one's social needs through religious activities carried out jointly or because they share the same values and beliefs.

Religiosity has fully mediated the relationship between socio-economic factors and environmental factors on the happiness of PLWHA in Denpasar City, while on the other hand religiosity does not mediate the relationship between psychological factors and the happiness of PLWHA in Denpasar City. The difference is due to socio-economic factors and environmental factors have a significant effect on religiosity, while psychological factors have no significant effect on religiosity. Szaflarski (2017) states that religiosity is important for people living with HIV AIDS (PLWHA). The religiosity of PLWHA has been defined as a multidimensional phenomenon that improves quality of life directly and through mediating factors. Religiosity helps PLWHA to cope with stress, especially stigma or discrimination. Religiosity interventions utilizing the power of prayer and meditation can increase the confidence of PLWHA in the community.

\section{CONCLUSION AND SUGGESTIONS}

The study of happiness analysis for People Living With HIV-AIDS (PLWHA) people in Denpasar resulted in several conclusions, including happiness in PLWHA in Denpasar based on 148 respondents with details of 62.17 percent of people living with HIV feeling happy, 30.40 percent very happy, and 7.43 percent less happy. Meanwhile, out of 83 PLWHA who had a male percentage of happiness level, 8.44 percent were unhappy, 62.65 percent were happy, and 28.91 percent were very happy, while women were 65 PLWHA with a percentage of happiness level of 6.16 percent were unhappy, 60 percent were happy, and 33.84 percent were very happy. Socio-economic factors and environmental factors have a positive and significant effect on the religiosity of PLWHA in Denpasar City. Meanwhile, psychological factors have no effect on the religiosity of PLWHA in Denpasar City. Socio-economic factors, psychological factors, and environmental factors do not affect the happiness of PLWHA in Denpasar City. Religiosity has a positive and significant effect on the happiness of PLWHA in Denpasar City. Religiosity was fully mediated the relationship between socio-economic factors and environmental factors with the happiness of PLWHA in Denpasar City, while on the other hand religiosity does not mediate the relationship between psychological factors and the happiness of PLWHA in Denpasar City.

HIV AIDS is a disease spread through viruses, the pattern of its spread is like an iceberg so it is very difficult to determine the actual number of people living with HIV AIDS in Denpasar, so awareness from various levels of society is needed to reduce the widespread of this disease. Suggestions from researchers include awareness of PLWHA to seek treatment to prolong their age and always behave positively, in terms of guarding themselves and not intending to spread this disease to others. The community must respect and respect PLWHA by not isolating or discriminating because in essence PLWHA are still God's creatures who have the right to live and be happy. The government, private sector, and religious leaders must play an active role in enlightening PLWHA to "repent for treatment" and arouse the spirit of life to reduce the negative effects of this disease. Besides that, all levels of society must also provide information on the importance of knowledge about HIV AIDS continually and how to mitigate it with the aim of suppressing the spread of HIV AIDS.

\section{REFERENCES}

1. Arriza, et.al. 2011. Memahami Rekonstruksi Kebahagiaan pada Orang dengan HIV AIDS (ODHA). Jurnal Psikologi Universitas Diponegoro Vol. 10, No 2.

2. Carr, Alan. 2004. Positive Psychology: The Science of Happiness and Human Strengths. New York: Brunner-Routledge.

3. Daradjat, Zakiah. 2003. Ilmu Jiwa Agama. Jakarta: Bulan Bintang.

4. Eddington, N. dan Shuman, R. 2005. Subjective Well Being (Happiness). Continuing Psychology Education: 6 Continuing Education Hours. 
5. Ghozali, Imam. 2008. Structural Equation Modeling. Edisi II. Universitas Diponegoro. Semarang.

6. Husein. 2003. Metode Penelitian Untuk Skripsi dan Tesis Bisnis. Cetakan Kedua. Jakarta: PT Raja Grafindo Persada.

7. Jaafar, et.al. 2008. The Index of Happiness of The Malaysian and Indonesian Peoples.

8. Komisi Penanggulangan AIDS Provinsi Bali. 2018. Laporan Situasi Temuan Kasus Kumulatif HIV AIDS di Provinsi Bali Tahun 1987-2017.

9. Lembaga Bantuan Hukum Provinsi Bali. 2018. Laporan Akhir Tahun.

10. Mubarak. 2008. IImu Kesehatan Masyarakat: Teori dan Apikasi. Gresik: Salema Medika.

11. Popova, Olga. 2019. Does Religiosity Explain Economic Outcomes ?. Institute for East and Southeast European Studies. ISSN: 2054-9571.

12. Rakhmat, Jalaluddin. 2004. Psikologi Agama: Sebuah Pengantar. Bandung: Mizan.

13. Seligman, M. E. P. 2005. Authentic Happiness: Using The New Positive Psychology to Realize Your Potential for Lasting Fulfi Ilment (Eva Yulia Nukman, Penerjemah). Bandung: PT. Mizan Pustaka.

14. Sugiyono. 2007. Metode Penelitian Bisnis. Bandung: Alfabeta.

15. Szaflarski, Magdalena. 2017. Spirituality and Religion Among HIV-Infected Inviduals. PMC. Curr HIV/AIDS Rep. 2013 Dec. 10(4): 324-332.

16. Thouless, H. 2000. Pengantar Psikologi Agama. Jakarta: Rajawali Press.

17. Todaro, M. P. dan Smith, S. C. 2006. Pembangunan Ekonomi. Edisi Kesembilan: Jilid Kesatu. Jakarta: Erlangga. 